\title{
Computational nanotechnology for functional coatings
}

\author{
Welchy Leite Cavalcanti, Michael Hoffmann, Marc Amkreutz, Peter Schiffels \\ From 6th German Conference on Chemoinformatics, GCC 2010 \\ Goslar, Germany. 7-9 November 2010
}

The computer simulations are powerful tools to understand and determine properties and behaviour for a broad range of materials and diverse applications, going to different time and length scales. In the applied computational chemistry group at IFAM the computer simulations have been successfully applied to support the experiments and develop coatings with improved functionalities. The computational nanotechnology has been carried out to develop enhanced coatings with different functionalities, for instance, anti-acing function, anti-corrosion performance, antifouling, adhesion, and release properties.

In this context the molecular state and the interactions among the coating matrix, the particles and the surface play a fundamental rule. The computer simulations are an effective way to determine properties influenced by the atomistic/molecular state.

In this presentation we will provide an overview of successful cases where we have applied the computational nanotechnology to support the experiments and develop coatings with improved functionalities, as anticorrosion, anti-icing and adhesion properties.

Published: 19 April 2011

\section{References}

1. Hörstermann $H$, Hentschke $R$, Amkreutz M, Hoffmann M, Wirts-Rütters M: J. Phys. Chem. B 2010, 114(51):17013-17024.

2. BMBF Project: Entwicklung eines Simulationstools zur Vorhersage des Härtungsschrumpfes und Quellverhaltens von Klebstoffen. Förderkennzeichen: 03X0502D; Laufzeit: 01.04.2007-31.03.2010, Projektpartner: Carl Zeiss Jena GmbH, Sartorius AG Göttingen, Wellmann Technologies $\mathrm{GmbH}$, Friedelsheim und Bergische Universität Wuppertal.

3. BMBF Project: Functional Surfaces for the Inhibition of Ice Growth., 09/ 2007 - 03/2011; BMBF-Sponsorship label 01RI0710B.

*Correspondence: welchy.leite.cavalcanti@ifam.fraunhofer.de Fraunhofer Institute for Manufacturing Technology and Advanced Materials in Bremen - IFAM, Bremen, D-28359, Germany
4. ZIM Project: Entwicklung von Korrosionsschutzkonzepten für Aluminium auf Basis polymerer Additive - KABA.

doi:10.1186/1758-2946-3-S1-024

Cite this article as: Cavalcanti et al:: Computational nanotechnology for functional coatings. Journal of Cheminformatics 2011 3(Suppl 1):O24.

\section{Publish with ChemistryCentral and every scientist can read your work free of charge \\ “Open access provides opportunities to our colleagues in other parts of the globe, by allowing anyone to view the content free of charge." \\ W. Jeffery Hurst, The Hershey Company. \\ - available free of charge to the entire scientific community \\ - peer reviewed and published immediately upon acceptance \\ - cited in PubMed and archived on PubMed Central \\ - yours - you keep the copyright \\ Submit your manuscript here: \\ http://www.chemistrycentral.com/manuscript/

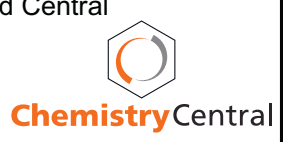

